\title{
Dynamics of the Variability of Heat and Moisture Supply Indicators and Irrigation Norms in the Conditions of the Astrakhan Region
}

\author{
Gennadii Olgarenko*, and Tatiana Kapustina
}

Federal State Budgetary Scientific Institution All-Russian Research Institute of Irrigation and Agricultural Water Supply Systems «Raduga», Kolomna urban district, Raduzhny, Russia

\begin{abstract}
During the scientific researches, scientific and methodological recommendations have been developed for determining the irrigation norms of crops for years with different water balance deficit availability, including a method for assessing and zoning a territory according to the coefficient of natural heat and moisture supply (moisture index) Mi, calculation models for rationing irrigation taking into account territorial and temporal variability, irrigation requirements for main crops, differentiated by natural and climatic zones within the Astrakhan Region. Based on statistical research and mathematical analysis of the main climatic indicators - air temperature and precipitation, trends and the degree of change in these indicators were investigated and identified according to observation data, as well as rational ecologically balanced regimes of irrigation of crops in the Astrakhan Region were calculated. According to the research results, based on the developed methodology, net irrigation requirements $(\mathrm{mm})$ were calculated for the main forage and vegetable crops in years of different humidity (supply), taking into account the climatic zones identified by the moisture index (Mi) in the Astrakhan Region.
\end{abstract}

\section{Introduction}

The most important global problem is the intense increase in demand for water, which threatens global development in the face of uncertainty and the risk of reduced water resources associated with growing demand for food, high rates of urbanization, and climate change, which negatively affect the world's freshwater supplies. Due to the growing shortage of water resources, ensuring availability and rational use of water resources is one of the Sustainable Development Goals adopted by the UN General Assembly as part of the 2030 Agenda.[1].

According to research by Roshydromet, global warming is happening 2.5 times faster in Russia than the average on the planet.[2] The average annual air temperature in 2019 exceeded the norm (the average temperature in 1961-1990) by $2.07^{\circ} \mathrm{C}$. In Russia, it becomes warmer by $0.47^{\circ} \mathrm{C}$ over 10 years, while the world average is $0.18^{\circ} \mathrm{C}$. Due to an unfavorable combination of hydrometeorological factors, in terms of an increase in temperatures with a

\footnotetext{
* Corresponding author: olgarenko@ mail.ru
} 
decrease in precipitation, due to an increase in climate aridity, the southern regions of Russia may suffer a drop in grain yield, which may exceed $20 \%$, especially since there is a parallel trend of deterioration in water supply and a growing shortage of water resources. Irrigated land is one of the main factors in ensuring the stability of agricultural production and ensuring food security. The output from an irrigated hectare is $2-5$ times higher than from a rainfed one, and labor productivity, the efficiency of using natural, material, and technical resources, including fertilizers, increasing by 2 - 3 times. Reclaimed land, which is less than $8.0 \%$ of the arable land, produces 50 percent of vegetables and up to 20 percent of feed and all rice.

World and domestic experience of scientific and industrial activities in the field of land reclamation and water management shows that the rational use of water provides not only high economic efficiency of irrigation but also its environmental safety $[4,5,6]$. The analysis of foreign and domestic scientific and technical materials proves that by improving the methodology for planned water use, the efficiency of irrigation can be increased by $40 . .50 \%$, therefore the main task in the operation of irrigation and drainage systems is the accurate regulation of water consumption for crops and rational management of water resources during irrigation $[7,8,9.10]$.

Therefore, an urgent task is to increase the efficiency of water resources management based on the improvement of computer information systems through the development of models for the regulation of water consumption, taking into account the probabilistic and nonlinear nature of the processes occurring in agrobiocenoses, the regularities of the cyclic process of the variability of hydrometeorological factors.

\section{Purpose of scientific research}

Methodological substantiation and calculation of irrigation norms for crops differentiated by natural and climatic zones of the Astrakhan Region considering environmental requirements.

\section{Materials and research methods}

Scientific research was carried out based on the study of scientific, methodological, regulatory, and technical materials available in the public domain, online resources, periodic domestic and foreign publications, reports on research work for a retrospective period of at least 20 years, the results of the FSBI "Upravleniye Astrakhanmeliovodkhoz" production activities for planning water use, rationing of irrigation and systemic water distribution. The tendencies and dynamics of changes in climatic indicators were found investigated according to the observational data for 1980 - 2020 on the meteorological stations of the Astrakhan Region based on mathematical analysis [2]. For each year of the long-term series, the meteorological stations were used to determine the sums of average monthly air temperatures and the sum of precipitation by months, their average values for the period from April to October, in which the vegetation of the main irrigated crops fits. The regularity of the dynamics of each climatic indicator was established using the integral method of dynamic modeling, reflecting the trend and the degree of its change for the calculated period [4].

Agroclimatic potential and irrigation requirements were calculated using the proprietary methodology of the All-Russian Research Institute Raduga, computer programs, and a database:

Calculation of irrigation regimes for crops and design standards for water demand. Methodological guidelines. Kolomna: FSBSI All-Russian Research Institute Raduga, OOO Inlight - 2012. 2014.

Planning of water use for irrigation of agricultural crops. M: FSBSI Rosinformagrotech, 
ROCK.xls "Calculation of parameters of crop irrigation regimes". Official registration certificate of computer programs No. 2004610996 dated April 22, 2004;

Raduga Irrigation "Calculation of the dynamics of agroclimatic resources and their regulation" Certificate of state registration of computer programs No. 2009610137 dated January 11, 2009

\section{Findings and discussion}

According to the data of meteorological stations of the Astrakhan Region, long-term series of meteorological data were formed and trends in temperature and precipitation changes for 1980-2020 were built (Figure 1).

According to the Kharabali meteorological station in the Astrakhan Region, it was found that it is possible to distinguish years with a maximum air temperature 1986, 1991, 1995, 2010 in the long-term series of meteorological data with a frequency of 5 years and maximum average temperatures $\left(20.2 \mathrm{IC} ; 20.1{ }^{\circ} \mathrm{C} ; 20.8^{\circ} \mathrm{C} ; 22.2^{\circ} \mathrm{C}\right)$, respectively for the period from April to September, and over the past 10 years, the frequency of years with maximum temperatures has been increasing, which was observed in $2005,2006,2007$, as well as in 2012, 2013, 2014 and 2020. (Figure 1).

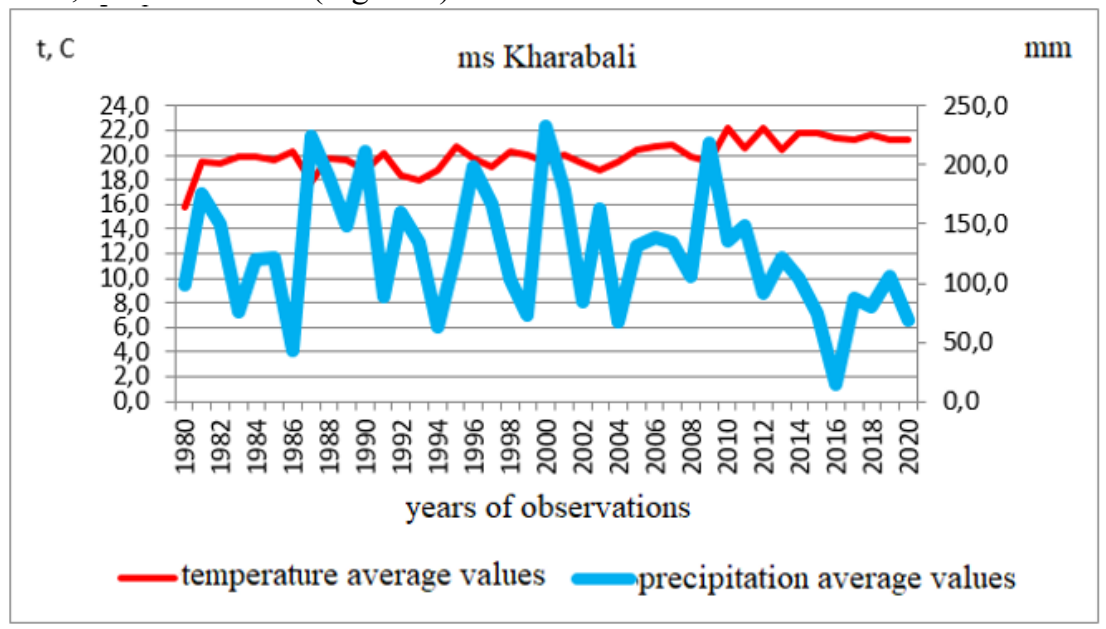

Fig. 1. Dynamics of temporal variability of the decade mean air temperatures and precipitation amounts, for the period from April to September 1980-2020.

Analyzing the meteorological data for the Astrakhan Region in a long-term series of data from 1980-2020, as well as temperature and precipitation data for the vegetation period 2018, 2019,2020 , a tendency to an increase in the sum of maximum temperatures and a decrease in precipitation is established, which increases anomalous deviations in this territory and is reflected in figures, which will affect the increase in irrigation requirements for irrigation of crops in the Astrakhan Region.

Thus, the maximum amplitudes observed in July of 2010, 2011, 2018, 2020 were 29.0$29.1^{\circ} \mathrm{C}$, maximum amplitudes in June of $2010,2012,2015,2019,2020$ were $26.1-27.2^{\circ} \mathrm{C}$, maximum values in August of 2017, 2016, 2014, 2010, 2007, 2006 were 27.0-28. $1^{\circ} \mathrm{C}$, which confirms the trend towards an increase in climate aridity in the last $10-15$ years. 


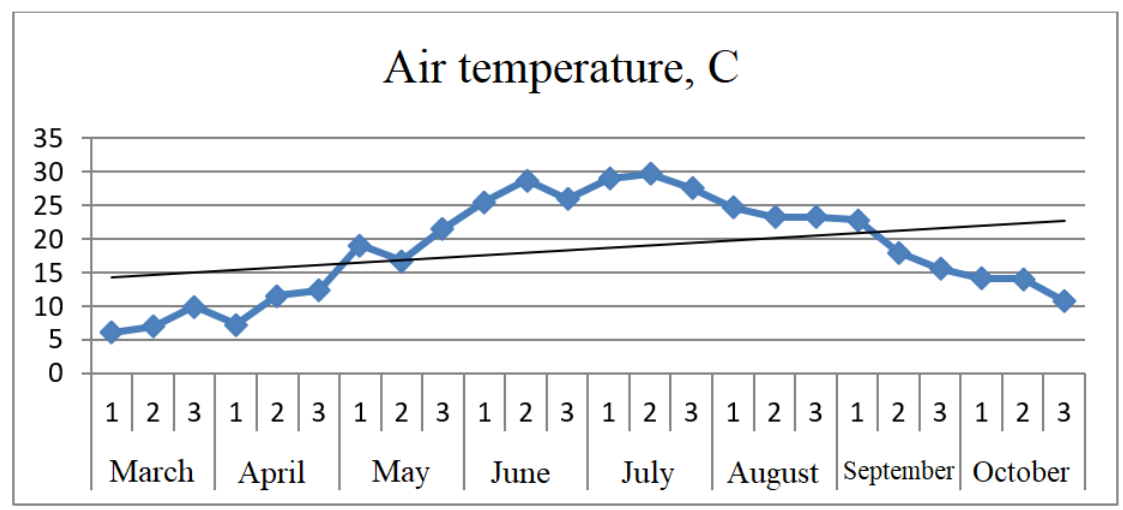

Fig. 2. An increasing trend in air temperature during the vegetation period according to the Kharabali meteorological station for 2020 .

An ambiguous picture is observed in these months with the amount of precipitation. So the average annual value of the amount of precipitation for the vegetation period is $166 \mathrm{~mm}$. However, there is a consistent pattern for decreasing precipitation. $218 \mathrm{~mm}$ were recorded in $2009,14.9 \mathrm{~mm}$ were recorded in 2016, and in 2020 precipitation was $66.7 \mathrm{~mm}$.

The minimum amount of precipitation falls in June-August. Thus, no precipitation was recorded from March to July of 2016, it was $3.3 \mathrm{~mm}$ and $11.6 \mathrm{~mm}$ in August and September respectively. The lowest precipitation values (0.3-0.5 mm) in July were noted in 2011, 2020, in August the minimum precipitation was noted in 2010, 2015, 2017, 2018. This reflects in the moisture supply decrease of the territory and the productivity of crops (Figures 4 and 5).

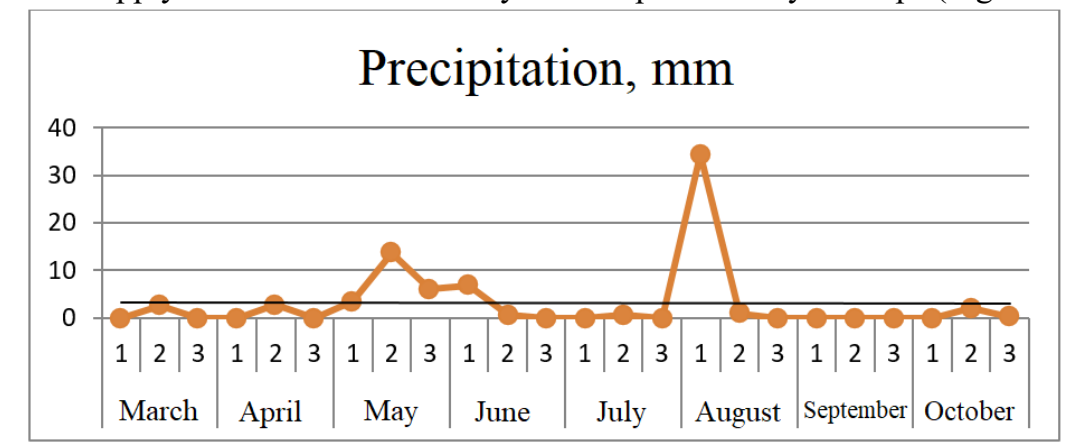

Fig. 3. The dynamics of precipitation changes during the vegetation period according to the Kharabali meteorological station for 2020 .

Data from three Zelenga meteorological stations. Khabarali and Cherny Yar of the Astrakhan Region (Southern FD) were used to assess the evaporation, heat, and water supply of the territory, and further calculate the irrigation parameters for crops (Figures 4 and 5). Over the past 10 years, humid years have been identified with a provision of $5 \%$ and $25 \%$ with a moisture index (Mi 0.37-0.28) - 2009, with an average moisture supply of 50\% - 2010,

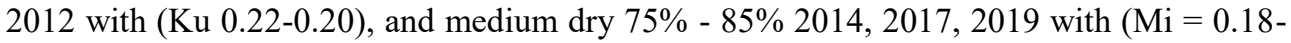
$0.15)$, dry $95 \%$ supply with $(\mathrm{Mi}=0.14-0,09)$ is $2015,2016,2018,2020$. 


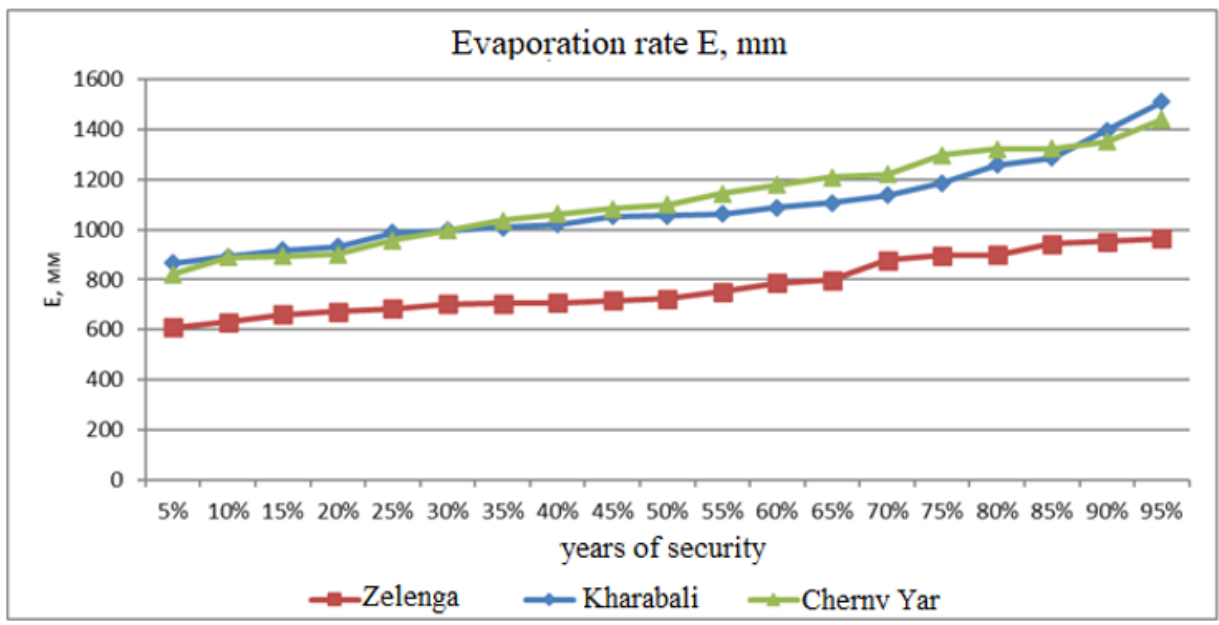

Fig. 4. Evaporation typical for the Astrakhan Region (according to the data from the Zelenga, Kharabali, Cherny Yar meteorological stations).

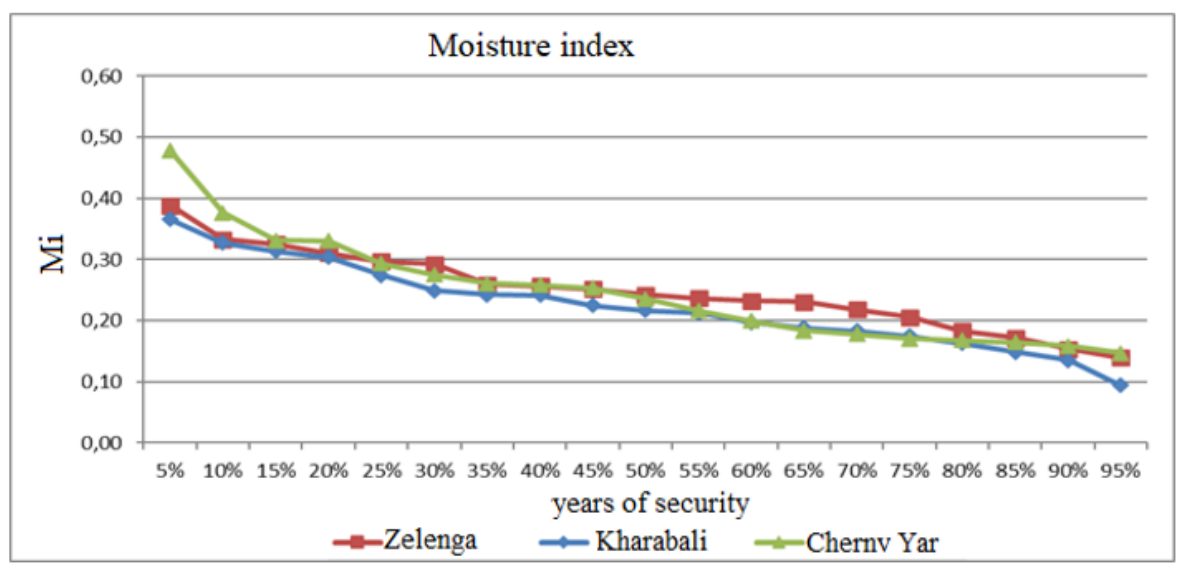

Fig. 5. The typical humidification coefficient for the Astrakhan Region (according to the data from the Zelenga, Kharabali, Cherny Yar meteorological stations).

The assessment of the heat and moisture supply coefficient shows that in recent years there has been a tendency towards a stable decrease in the heat and moisture supply coefficient and the frequency of years with insufficient precipitation, which can lead to a change in the natural and climatic zone from dry steppe to semidesert. Also, the decreasing dynamics in the coefficient of heat and moisture supply leads to an increase in the total water consumption for crops.

During the scientific researches, a scientific and methodological document has been developed for determining the irrigation norms of crops for years with different water balance deficit availability, including a method for assessing and zoning a territory according to the coefficient of natural heat and moisture supply $\mathrm{Ku}$, calculation models for rationing irrigation taking into account territorial and temporal variability, irrigation requirements for main crops, differentiated by natural and climatic zones within the Astrakhan Region (Figure 6). 


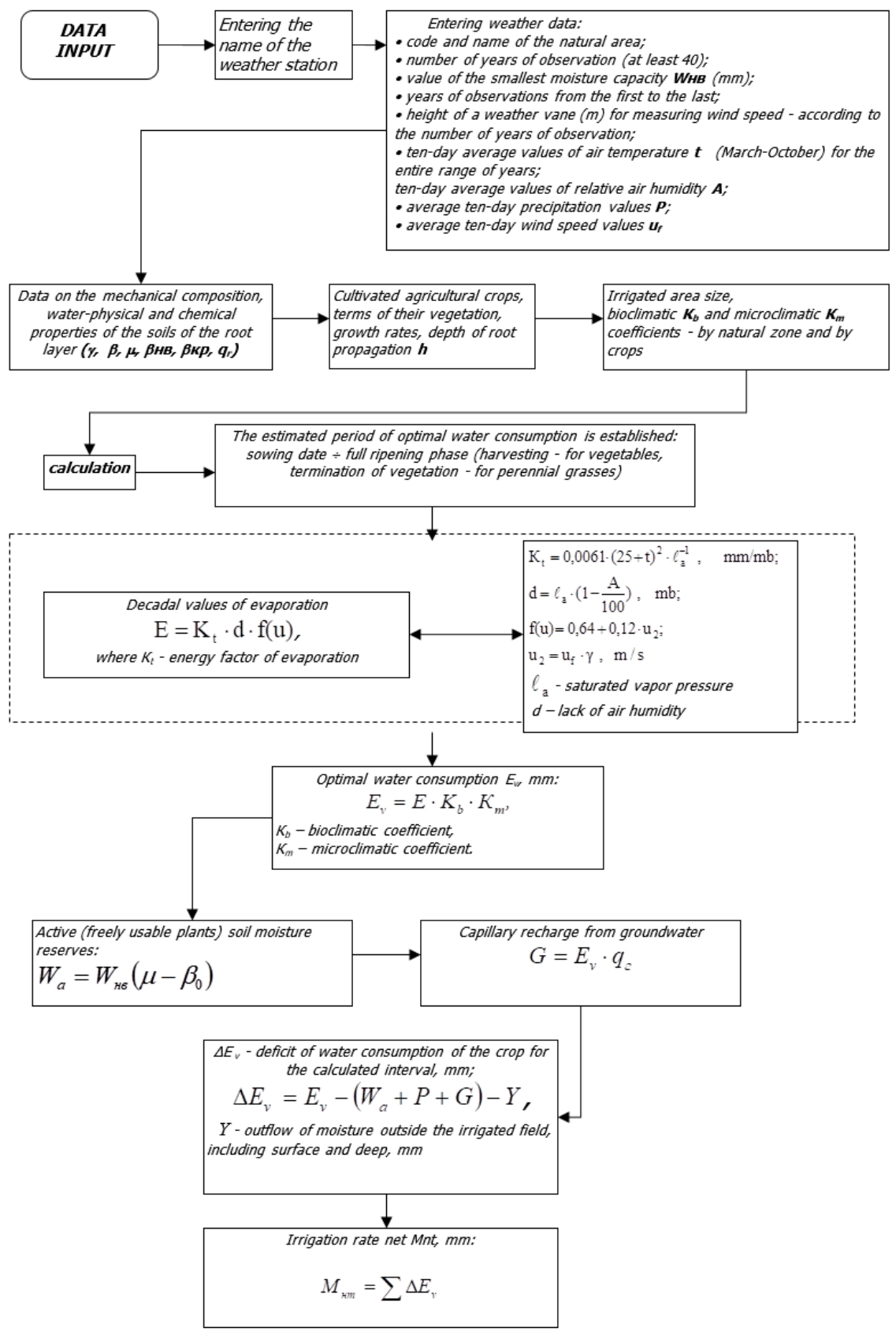

Fig. 6. Flowchart and algorithm for calculating the water consumption deficit.

The tendency of the variability of irrigation norms deficits depending on moisture supply, with differentiation by natural and climatic zones, is shown in Tables 1-3. The variability of irrigation norms by territory and time necessitates a differentiated approach to the choice of the year of the calculated irrigation provision and the development of irrigation regimes according to a specific zone and year of moisturizing. At the same time, a significant role is 
assigned to the position and dynamics of groundwater, their part in the water balance of the soil and root zone.

Table 1. Environmentally friendly irrigation norms $(\mathrm{mm})$ calculated based on average annual data from Zelenga meteorological station $(\mathrm{Mi}=0.25)$.

\begin{tabular}{|c|c|c|c|c|}
\hline \multirow[t]{2}{*}{ Crop } & \multicolumn{4}{|c|}{$\begin{array}{l}\text { Probabilistic (secured) values of the net irrigation } \\
\text { requirement at } \mathrm{P} \% \text { supply, mm }\end{array}$} \\
\hline & $25 \%$ & $50 \%$ & $75 \%$ & $95 \%$ \\
\hline Winter crops & 120 & 135 & 170 & 220 \\
\hline spring crops & 140 & 180 & 220 & 250 \\
\hline late potatoes & 210 & 260 & 310 & 350 \\
\hline early potatoes & 120 & 160 & 190 & 220 \\
\hline grain maize & 220 & 310 & 400 & 450 \\
\hline maize for silage & 160 & 230 & 350 & 410 \\
\hline fodder beet & 154 & 210 & 280 & 280 \\
\hline beetroot & 190 & 220 & 320 & 370 \\
\hline past alfalfa & 314 & 350 & 421 & 472 \\
\hline annual herbs & 230 & 270 & 320 & 360 \\
\hline late cabbage & 230 & 310 & 360 & 420 \\
\hline early cabbage & 150 & 230 & 260 & 350 \\
\hline vegetables (tomatoes) & 280 & 330 & 380 & 430 \\
\hline vegetables (carrots) & 220 & 280 & 320 & 380 \\
\hline vegetables (onions) & 180 & 230 & 290 & 330 \\
\hline melon (watermelon) & 260 & 320 & 380 & 450 \\
\hline $\begin{array}{l}\text { fruit-bearing garden (apple, } \\
\text { pear, cherry, apricot) }\end{array}$ & 240 & 300 & 360 & 400 \\
\hline grapes & 180 & 230 & 320 & 380 \\
\hline
\end{tabular}

Table 2. Environmentally friendly irrigation norms $(\mathrm{mm})$ calculated based on average annual data from Kharabali meteorological station $(\mathrm{Ku}=0.22)$

\begin{tabular}{|l|c|c|c|c|}
\hline \multirow{2}{*}{\multicolumn{1}{|c|}{ Crop }} & \multicolumn{4}{|c|}{ Probabilistic (secured) values of the net irrigation requirement } \\
& \multicolumn{4}{|c|}{ at P\% supply, mm } \\
& $\mathbf{2 5 \%}$ & $\mathbf{5 0 \%}$ & $\mathbf{7 5 \%}$ & $\mathbf{9 5 \%}$ \\
\cline { 2 - 5 } & 140 & 180 & 220 & 260 \\
\hline winter crops & 160 & 210 & 280 & 300 \\
\hline spring crops & 220 & 270 & 340 & 380 \\
\hline late potatoes & 140 & 180 & 230 & 270 \\
\hline Early potatoes & 270 & 350 & 420 & 480 \\
\hline grain maize & 248 & 310 & 390 & 430 \\
\hline maize for silage & 200 & 230 & 325 & 340 \\
\hline fodder beet & 210 & 250 & 350 & 390 \\
\hline beetroot & 350 & 420 & 470 & 530 \\
\hline past alfalfa & 270 & 320 & 380 & 430 \\
\hline annual herbs & 280 & 370 & 400 & 450 \\
\hline late cabbage & 200 & 270 & 320 & 390 \\
\hline early cabbage & 295 & 350 & 410 & 474 \\
\hline vegetables (tomatoes) & 250 & 310 & 370 & 410 \\
\hline vegetables (carrots) & 210 & 250 & 320 & 350 \\
\hline vegetables (onions) & & & &
\end{tabular}


Continuation of table 2

\begin{tabular}{|l|c|c|c|c|}
\hline Melon (watermelon) & 290 & 380 & 440 & 510 \\
\hline $\begin{array}{l}\text { Fruit-bearing garden } \\
\text { (apple, pear, cherry, } \\
\text { apricot) }\end{array}$ & 270 & 330 & 400 & 450 \\
\hline Grapes & 280 & 320 & 410 & 480 \\
\hline
\end{tabular}

Table 3. Environmentally friendly irrigation norms $(\mathrm{mm})$ calculated based on average annual data from Cherny Yar meteorological station $(\mathrm{Ku}=0.20)$.

\begin{tabular}{|l|c|c|c|c|}
\hline \multirow{2}{*}{ Crop } & \multicolumn{4}{|c|}{$\begin{array}{c}\text { Probabilistic (secured) values of the net } \\
\text { irrigation requirement at P\% supply, mm }\end{array}$} \\
\cline { 2 - 5 } & $\mathbf{2 5 \%}$ & $\mathbf{5 0 \%}$ & $\mathbf{7 5 \%}$ & $\mathbf{9 5 \%}$ \\
\hline winter crops & 180 & 200 & 240 & 290 \\
\hline spring crops & 200 & 240 & 280 & 320 \\
\hline late potatoes & 220 & 290 & 350 & 390 \\
\hline early potatoes & 150 & 200 & 240 & 280 \\
\hline grain maize & 290 & 370 & 450 & 505 \\
\hline maize for silage & 260 & 330 & 400 & 450 \\
\hline fodder beet & 220 & 250 & 340 & 395 \\
\hline beetroot & 231 & 290 & 370 & 420 \\
\hline past alfalfa & 400 & 470 & 530 & 610 \\
\hline annual herbs & 305 & 344 & 386 & 429 \\
\hline late cabbage & 300 & 390 & 425 & 480 \\
\hline early cabbage & 210 & 280 & 330 & 410 \\
\hline vegetables (tomatoes) & 310 & 370 & 440 & 510 \\
\hline vegetables (carrots) & 274 & 320 & 390 & 430 \\
\hline vegetables (onions) & 225 & 280 & 345 & 380 \\
\hline watermelon & 320 & 400 & 510 & 570 \\
\hline $\begin{array}{l}\text { fruit-bearing garden (apple, } \\
\text { pear, cherry, apricot) }\end{array}$ & 290 & 385 & 430 & 490 \\
\hline grapes & 310 & 360 & 420 & 460 \\
\hline
\end{tabular}

Environmentally friendly irrigation norms for crops in various natural landscapes for $75 \%$ of the availability of the year are presented in Table 4. 
Table 4. Environmentally friendly irrigation norms (net) of crops for the Astrakhan Region $75 \%$ of the supply during sprinkling irrigation

\begin{tabular}{|c|c|c|c|c|c|c|}
\hline \multirow[b]{3}{*}{ Crop } & \multicolumn{6}{|c|}{ Irrigation requirement, $\mathrm{m} 3 / \mathrm{ha}$ 75\% supply } \\
\hline & \multirow[b]{2}{*}{$\begin{array}{l}\text { Delta (Zelenga } \\
\text { meteorological } \\
\text { station) }\end{array}$} & \multicolumn{4}{|c|}{$\begin{array}{c}\text { Floodplain at the level of groundwater } \\
\text { occurrence (Khabarali meteorological } \\
\text { station) }\end{array}$} & \multirow{2}{*}{$\begin{array}{c}\text { Stepp } \\
\text { e } \\
\text { (Cher } \\
\text { ny } \\
\text { Yar } \\
\text { meteo } \\
\text { rologi } \\
\text { cal } \\
\text { statio } \\
\text { n) }\end{array}$} \\
\hline & & $\begin{array}{c}1.0-1.5 \\
\mathrm{~m}\end{array}$ & $\begin{array}{c}1.5-2.0 \\
\mathrm{~m}\end{array}$ & $\begin{array}{c}2.0-2.5 \\
\mathrm{~m}\end{array}$ & $\begin{array}{c}>\mathbf{3 . 0} \\
\mathbf{m}\end{array}$ & \\
\hline Winter crops & 1700 & 1450 & 1700 & 2000 & 2200 & 2400 \\
\hline Spring crops & 2200 & 1848 & 2156 & 2492 & 2800 & 2800 \\
\hline Late potatoes & 3100 & 2482 & 2924 & 3162 & 3400 & 3500 \\
\hline Early potatoes & 1900 & 1679 & 1978 & 2139 & 2300 & 2400 \\
\hline Grain maize & 4000 & 3200 & 3680 & 4400 & 4200 & 4500 \\
\hline Maize for silage & 3500 & 2574 & 3000 & 3471 & 3900 & 4000 \\
\hline Fodder beet & 2800 & 2145 & 2502 & 2892 & 3250 & 3400 \\
\hline Beetroot & 3200 & 2310 & 2695 & 3115 & 3500 & 3700 \\
\hline Past alfalfa & 4210 & 3100 & 3619 & 4183 & 4700 & 5300 \\
\hline Annual herbs & 3200 & 2508 & 2936 & 3380 & 3800 & 3860 \\
\hline Late cabbage & 3600 & 2640 & 3080 & 3560 & 4000 & 4250 \\
\hline Early cabbage & 2600 & 2112 & 2464 & 2848 & 3200 & 3300 \\
\hline $\begin{array}{l}\text { Vegetables (tomatoes, } \\
\text { peppers, eggplants) }\end{array}$ & 3800 & 3000 & 3526 & 3810 & 4100 & 4400 \\
\hline Vegetables (carrots) & 3200 & 3219 & 3515 & 3626 & 3700 & 3900 \\
\hline Vegetables (onions) & 2900 & 2784 & 3040 & 3136 & 3200 & 3450 \\
\hline Watermelon & 3800 & 2900 & 3390 & 3916 & 4400 & 5100 \\
\hline $\begin{array}{l}\text { Fruit-bearing garden } \\
\text { (apple, pear, cherry, } \\
\text { apricot) }\end{array}$ & 3600 & 2640 & 3070 & 3560 & 4000 & $\begin{array}{l}4300 \\
5300\end{array}$ \\
\hline Grapes & 3200 & 2706 & 3157 & 3649 & 4100 & 4200 \\
\hline
\end{tabular}

Based on the research results, the dependences of the change in $\Delta \mathrm{Yi}=1-\mathrm{Yi} / \mathrm{Ymax}$ were built - the relative decrease in yield in shares of the yield value, due to the change in $\Delta \ell_{v i}$ of the relative decrease in water supply (Table 5).

The elements of the equation are defined as follows:

$$
\Delta \ell_{v i}=1-\frac{\mathrm{Evi}}{\text { Evon } \mathrm{T}}
$$

where: $\Delta \ell_{v i}$ - the relative decrease in water supply (actual water consumption) of the crop in shares of $E v_{\text {opt }}$,

$E v_{\text {opt }}$ - optimal water consumption at optimal water regime of the soil and the level of the plants' water supply, mm;

$E v i$ - water consumption at the actual plants' water supply, in a specific vegetation period, $\mathrm{mm}$. 
Table 5. Equations of connection between the relative decrease in yield and a decrease in the natural water supply of the vegetation period of crops.

\begin{tabular}{|c|c|}
\hline Crop & Equations of connection $\Delta \mathbf{y i}=\boldsymbol{f}\left(\Delta \ell_{v i}\right)$ \\
\hline Winter wheat & $\Delta y i=-0.003+0.63 \Delta \ell_{v i}+0.77 \Delta \ell_{v i}{ }^{2}$ \\
\hline Alfalfa for hay & $\Delta y_{i}=-0.002+0.33 \Delta \ell_{v i}+1.07 \Delta \ell_{v i}{ }^{2}$ \\
\hline Sugar beet & $\Delta y_{i}=-0.0019+0.45 \Delta \ell_{v i}+0.75 \Delta \ell_{v i}{ }^{2}$ \\
\hline Maize for silage & $\Delta y_{i}=-0.026+0.64 \Delta \ell_{v i}+0.86 \Delta \ell_{v i}{ }^{2}$ \\
\hline Late cabbage & $\Delta y_{i}=-0.024+1.08 \Delta \ell_{v i}+0.36 \Delta \ell_{v i}{ }^{2}$ \\
\hline Late potatoes & $\Delta y_{i}=-0.025+0.91 \Delta \ell_{v i}+0.45 \Delta \ell_{v i}{ }^{2}$ \\
\hline
\end{tabular}

Using the obtained equations of connection, it is possible to establish the relative and absolute values of the decrease in yield from the lack of water supply (water consumption deficit) of crops cultivated in the region. Depending on the availability of precipitation, natural moisturizing has a significant impact on the value of the crop yield. In dry and very arid zones, the crop yield decreases to almost zero as the deficit in rainfall increases. When predicting the crop yield in arid natural and climatic zones, it is important to take into account the influence of the moisture supply of the vegetation period when rationing irrigation, since one of the main limiting factors in the process of plant growth and development is moisture supply.

\section{Conclusion}

In terms of moisture supply, two main agroclimatic regions can be distinguished In the Astrakhan Region: - very dry, which includes Krasnoyarsk, Volodarsky, and Kamyzyaksky districts, and dry, which includes the rest of the region. As a result of the research work, rationing of irrigation was carried out using the water balance method, the dynamics of the elements of which is determined by a large number of stochastic hydrometeorological factors. Elements such as evapotranspiration, precipitation, soil moisture reserves vary significantly in space and time, and their variability, in turn, has a strong effect on the irrigation regime and crop yields. The proposed method for calculating irrigation norms for crops makes it possible to assess the bioclimatic potential and prospects for the development of hydro amelioration, substantiate the feasibility and efficiency of irrigation development, the choice of the structure of crop rotations, and the most valuable crops for cultivation on irrigated lands, to optimize the design irrigation regimes and technical and operational parameters of irrigation systems. The recommended irrigation requirements for the conditions of the Astrakhan Region are ecologically friendly considering the difficult soil and climatic conditions of the Astrakhan Region, soil salinity, depth, and mineralization of groundwater. These studies made it possible to reveal the reaction of various crops to the lack (deficiency) of natural moisture and to determine design norms and irrigation regimes for a number of crops cultivated in the region.

\section{References}

1. UN Sustainable Development Goals Report 2020. https://unstats.un.org/sdgs/indicators/database

2. G.V. Gruza, E. Ya. Rankova, Fluctuations and Climate Change in Russia. Izv. RAS. Physics of the Atmosphere and Ocean 39(2) (2003) 
3. O.D. Sirotenko, A.D. Kleshchenko, V.N. Pavlova, E.V. Abashina, A.K. Semendyaev, Agrofizika 3, 31 (2011)

4. G.V. Olgarenko, T.A. Kapustina, I.M. Avanesyan, Cyclicity of climatic indicators and their impact on the ecological and reclamation state of agricultural landscapes in the Russian Federation (2006)

5. R. Allan, L. Pereira, M. Smith, Crop evapotranspiration - Guidelines for computing crop water requirements-FAO Irrigation and drainage paper 56 (1998)

6. Water Saving in Agriculture - Irrig. and Drain. J. 69, 4 (2020)

7. P. Hisey, Irrig. and Green Ind. J, 24, 2, p. 28 (2020)

8. B. Fair, Irrig. and Green Ind. J. 24, 2, p. 32 (2020)

9. G.V. Olgarenko (ed.), Rationing of water consumption and irrigation regimes for agricultural crops for natural and climatic zones of the Central, Volga, Ural, Siberian and North Caucasian federal districts of the Russian Federation. Guidelines. Kolomna: FGBNU VNII "Raduga", 108 p. (2018)

10. M. Svoboda, B.A. Fuchs, IDMP, Integrated. (2016). Handbook of Drought Indicators and Indices. URL: https://library.wmo.int/doc_num.php?explnum_id=3192 